PACS: $03.65 . \mathrm{Sq}$

\title{
ENERGY EXCHANGE BETWEEN THE FIELD AND THE ACTIVE MEDIUM OF THE WAVEGUIDE
}

\author{
(D) Volodymyr Kuklin*, (D)Eugen Poklonskiy \\ V.N. Karazin Kharkiv National University, Kharkiv, Ukraine \\ Svobody Sq. 4, Kharkiv, Ukraine, 61022 \\ *E-mail:kuklinvm1@gmail.com
}

Received July 2, 2019; revised August 2, 2019; accepted August 29, 2019

The work based on a semiclassical description, presents the results of studying the processes of absorption and radiation of a field in the form of a standing wave in a waveguide filled with a two-level active medium. Under conditions of spatial inhomogeneity of the field intensity, interference of quasi-periodic oscillations of population inversion occurs in different local regions of the waveguide. A quasiperiodic change in population inversion is determined by the Rabi frequency, which is known to be associated with the probability of induced radiation with a positive population inversion, or induced absorption with its negative value. Since the population inversion change is accompanied by absorption or emission of field quanta, this leads to the exchange of energy between the field and the active medium located in the waveguide. It is shown that the attenuation of a large-amplitude field to a waveguide filled with an unexcited active medium is nonlinear. In the developed mode, this process has the character of energy exchange between the field and the active medium. In this case, the wave attenuation is replaced by its growth, just as it happens in the wellknown case of Landau kinetic damping. Competition of the processes of radiation and absorption leads to the fact that the nature of the oscillations (nutations) of the population inversion at different points of the waveguide space is different. The interference of nonsynchronous spatially localized oscillations of the population inversion in the volume of the waveguide leads to changes in the field amplitude. The paper also discusses the process of field excitation in a waveguide with a pre-inverted two-level active medium, taking into account external mechanisms for the absorption of wave energy. Consideration of these problems is important for understanding the processes of generation of induced radiation, which, as noted by C. Towns, is to a large extent coherent radiation. KEYWORDS: absorption and radiation of the field, two-level active medium, Rabi frequency, interference of oscillations of population inversion.

The quasiclassical model of the interaction of the field and the active system, in particular, a system of dipoles with two energy levels, allowed consider these phenomena in the media [1-4]. This model combined a quantummechanical approach using a density matrix to describe a system of dipoles, and the classical field representation in limited volumes, particularly in waveguides. An important characteristic of the dynamics of a dipole system in the presence of an external electric field is the Rabi frequency, which determines the probabilities of induced emission or absorption of field quanta $[1,2]$ and describes the population inversion oscillations (nutation).

Previously, the focus was on the processes of relaxation and excitation of a quantum system in the external media [1-2], as well as modes of oscillation generation in unbounded media with nonlinearity, dispersion and finite temperature [3-4] (see also [5-9]). However, a consequence of the limitations of the system is the appearance of line spectra of oscillations and standing waves, which leads to a noticeable non-uniformity of the field intensity distribution. This can change the nature of the field interaction with the active medium placed in the waveguide, because in areas with different field intensities the Rabi frequency and, accordingly, the nature of the oscillatory behavior of the population inversion of the active substance will differ significantly.

Below we discuss the influence of the spatial inhomogeneity of the field on the nature of its interaction with the active medium. Let us consider the features of the absorption and excitation of a field in a waveguide filled with an active two-level medium. Let the field in the waveguide be a standing wave, and at each point in space, it changes only with time. We show that the interference of quasi-periodic changes in population inversion in different areas with the Rabi frequency, depending on the local field intensity in these areas, determines both the nature of the attenuation of a large amplitude wave and the nature of the field generation.

The aim of the article is to present the physical mechanism of attenuation of a large-amplitude wave in a waveguide filled with an active two-level medium, as well as to elucidate the nature of electromagnetic field excitation at finite levels of population inversion.

\section{RABI FREQUENCY}

If the waveguide is filled with an active substance, the semiclassical theory, which was actively discussed in particular in [2-4], describes the generation of oscillations. To simplify the description, we consider a one-dimensional model for disturbances of the electric field $E$, polarization $P$ and population inversion $\mu$ that slowly varies with time, describing the excitation of electromagnetic oscillations in a two-level active medium, whose equations can be represented as

$$
\frac{\partial^{2} E}{\partial t^{2}}+\delta \frac{\partial E}{\partial t}-c^{2} \frac{\partial^{2} E}{\partial x^{2}}=-4 \pi \frac{\partial^{2} P}{\partial t^{2}}
$$




$$
\begin{gathered}
\frac{\partial^{2} P}{\partial t^{2}}+\omega^{2} \cdot P=-\frac{2 \omega\left|d_{a b}\right|^{2}}{\hbar} \mu E, \\
\frac{\partial \mu}{\partial t}=\frac{2}{\hbar \omega}<E \frac{\partial P}{\partial t}>
\end{gathered}
$$

where the frequency of the transition between the levels corresponds to the field frequency. We are neglect the line width in the equation for polarization and the inversion relaxation due to external causes. There are $\delta$ - the decrement of field absorption in the medium, $d_{a b}$ - the matrix element of the dipole moment (or rather its projection on the direction of the electric field), the population difference $\mu=n \cdot\left(\rho_{a}-\rho_{b}\right)$ in the unit volume, and the relative populations $\rho_{a}, \rho_{b}$ of levels in the absence of a field, $n$ is the density of the dipoles of the active medium. Fields are represented by $E=\left[E(t) \cdot \exp \{-i \omega t\}+E^{*}(t) \cdot \exp \{i \omega t\}\right] / 2$ and $P=\left[P(t) \cdot \exp \{-i \omega t\}+P^{*}(t) \cdot \exp \{i \omega t\}\right] / 2$. Wherein $<E^{2}>=|E(t)|^{2} / 2$.

For slowly varying field amplitudes $E(t)$ and polarizations $P(t)$, the following equations are valid

$$
\begin{gathered}
\frac{\partial E(t)}{\partial t}+\delta \cdot E(t)=2 i \pi \omega P(t), \\
\frac{\partial P(t)}{\partial t}=\left|d_{a b}\right|^{2}(\mu / \hbar) \frac{E(t)}{i} .
\end{gathered}
$$

Using (3) - (5) in the absence of energy loss, you can get the ratio

$$
\frac{\partial}{\partial t}\left(\frac{\partial \mu}{2|E| \partial t}\right)^{2}=-\frac{\left|d_{a b}\right|^{2}}{4 \hbar^{2}} \frac{\partial}{\partial t} \mu^{2}
$$

from which the equation for population inversion follows

$$
\frac{\partial \mu}{\partial t}=i \frac{2\left|E \| d_{a b}\right|}{2 \hbar} \mu
$$

the meaning of this equation is that population inversion oscillates with the Rabi frequency $\Omega$ (the so-called nutation of population inversion)

$$
\Omega=\frac{2\left|E \| d_{a b}\right|}{2 \hbar} .
$$

It can be shown [10] that equation (7) remains valid also in the case when the energy loss is significant, that is, at $\delta \neq 0$.

\section{EQUATIONS OF MODEL}

Here it is useful to pay attention to the fact that population inversion is a real value. Therefore, only the real part of the expression $\operatorname{Re} \mu=\left(\mu+\mu^{*}\right) / 2$ we may use. From equation (3) you can get the law of energy conservation in the system

$$
\operatorname{Re}\left(\mu-\mu_{0}\right)=N_{0}-N-\delta \int_{0}^{t} N\left(t^{\prime}\right) d t^{\prime}
$$

We use the following notation:

$N=\sum_{j=1}^{S} N_{j}, N_{j}=2 \cdot \frac{1}{S} N \cdot \operatorname{Cos}^{2}\left\{2 \pi \frac{j}{S}+\alpha\right\}, \quad \mu_{j}=\mu_{0 j} \cdot \exp \left(i \Phi_{j}\right)$ - initial population inversion, $N=|E|^{2} / 4 \pi \hbar \omega \mu_{0}-$ relative number of quanta in the system. Here the waveguide length is chosen equal to the radiation wavelength ${ }^{1}$, the constant phase. The spatial structure of the field, which is determined by the boundary conditions, the nature of

\footnotetext{
${ }^{1}$ If the waveguide length is longer, but a multiple of the emission wavelength, which, generally speaking, the description will not change qualitatively, only the value of the damping factor will be different.
} 
reflection and radiation, will be considered constant for fixed values and, the time scale will be determined from the relation $\tau=\Omega_{0} t=\frac{(4 \pi \omega)^{1 / 2} \sqrt{\left|\mu_{0}\right|}\left|d_{a b}\right|}{\hbar^{1 / 2}} t$, then $\delta_{1}=\delta / \Omega_{0}$, we divide the entire system length into segments with a single population inversion value $0<j \leq S=100$.

Consider the case when the field in the waveguide will attenuate in the presence of an unexcited active medium. In this case, we choose the initial conditions

$$
M_{j}(0)=M_{0 j}=-\frac{1}{S}, \Phi_{j}(\tau=0)=0, N(\tau=0)=N_{0}=1.45, N_{j}(\tau=0)=2 \frac{1}{S} \cdot N_{0} \cdot \operatorname{Sin}^{2}\left\{2 \pi \frac{j}{S}\right\} .
$$

When this equation (7), (9) can be written as

$$
\begin{gathered}
\frac{\partial \Phi_{i}}{\partial \tau}=\sqrt{N_{j}} \\
\sum_{j=1}^{S} M_{j 0} \operatorname{Cos} \Phi_{j}+1=N_{0}-N .
\end{gathered}
$$

If the active medium is excited, it is possible to consider problems of field excitation in a waveguide under conditions of different absorption levels. You can choose the initial conditions $M_{j}(0)=M_{0 j}=S^{-1}, \Phi_{j}(\tau=0)=0$, $N(\tau=0)=N_{0}=0.001, N_{j}(\tau=0)=2 \frac{1}{S} \cdot N_{0} \cdot \operatorname{Sin}^{2}\left\{2 \pi \frac{j}{S}\right\}$

In this notation, the system of equations (7), (9) is written in the form

$$
\begin{gathered}
\frac{\partial \Phi_{i}}{\partial \tau}=\sqrt{N_{j}} \\
\sum_{j=1}^{S} M_{j 0} \operatorname{Cos} \Phi_{j}-1=N_{0}-N-\delta_{1} \int_{0}^{\tau} d \tau^{\prime} N\left(\tau^{\prime}\right)=N_{0}-\sum_{j=1}^{S} N_{j}-\delta_{1} \int_{0}^{\tau} d \tau^{\prime} N\left(\tau^{\prime}\right) .
\end{gathered}
$$

RESULTS OF NUMERICAL CALCULATIONS

Absorption of a large amplitude wave in the waveguide with unexcited active medium

Each region of space of the active medium contributes to the total number of field quanta in the waveguide. The field in the waveguide is a standing wave, so the amplitude of the field and the Rabi frequency at each point in the waveguide space depend only on time. An increase in population inversion leads to absorption of field quanta by the active medium, a decrease in population inversion, on the contrary, increases the number of quanta in the system. In each region of space, the Rabi frequency is different and the total field is formed under the influence of the interference of local oscillations (local nutation) of population inversion in the entire waveguide volume. For this case, described by equations (10) and (11), changes in the relative number of quanta in the system $N=N(\tau)$ are shown in Fig.1. The first minimum $N_{\min }=0.047$ and the maximum field $N_{\max }=0.75$ are reached at $\tau=45.47$ and $\tau=90.92$, respectively.

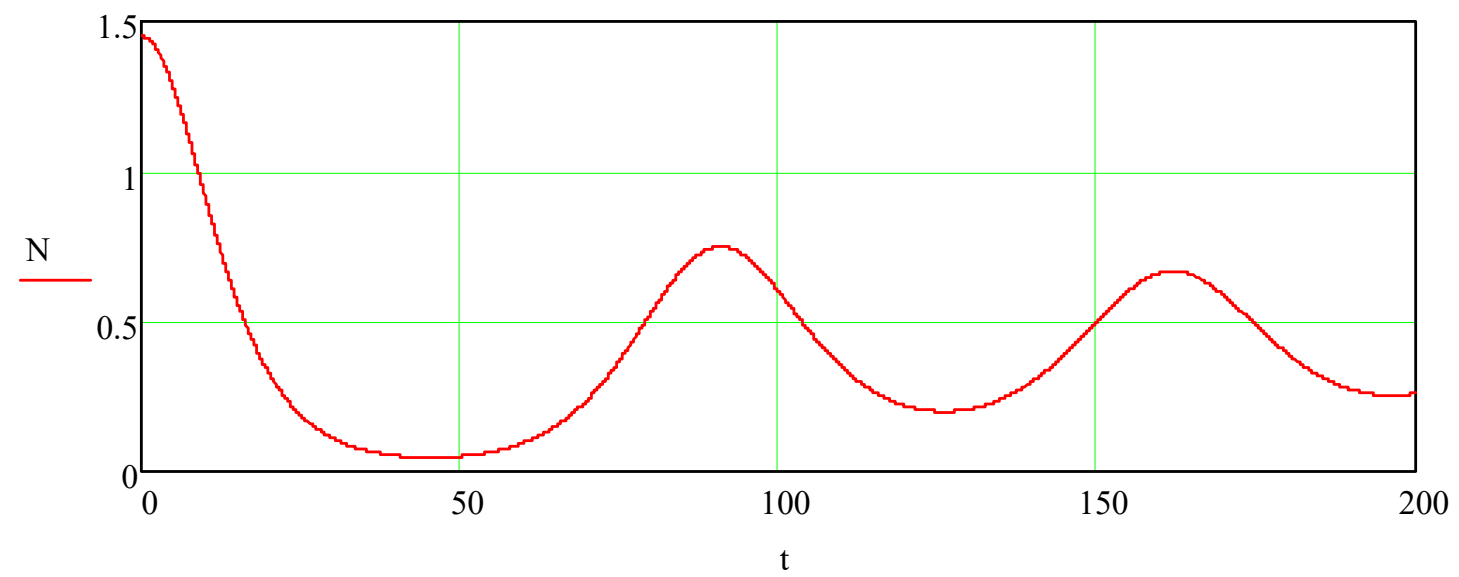

Fig. 1. The process of field attenuation - the relative number of quanta $N=N(\tau)$ in the system with time in the absence of external losses $\left(\delta_{1}=0\right)$. 
Periodic changes in the number of quanta in the nonlinear mode are attenuated due to the interference of population inversion oscillations in different segments. The behavior of the population inversion of individual segments is presented in detail in Fig.2. The linear decrement of the field attenuation $\delta_{1 N}=(d N / N d \tau)$ in the selected time scale at the linear stage of the process, obtained from the analysis of Fig. 1 is equal to $\delta_{1 N}=-0.113$

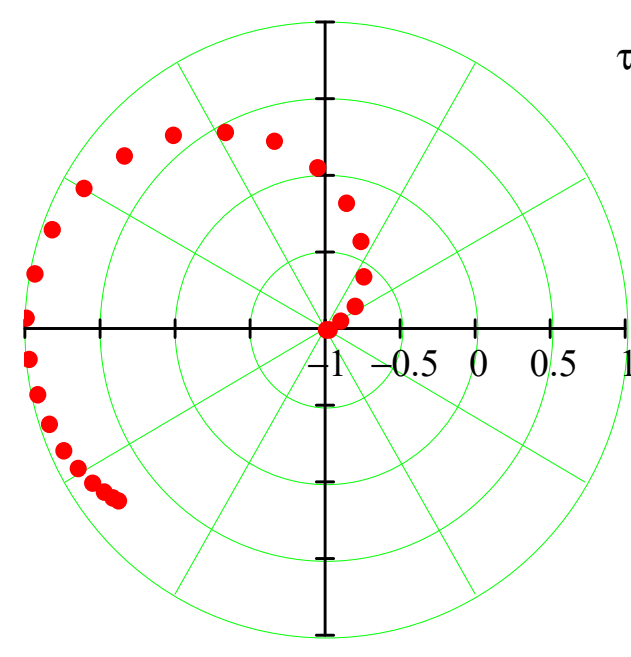

$\tau=45.47$
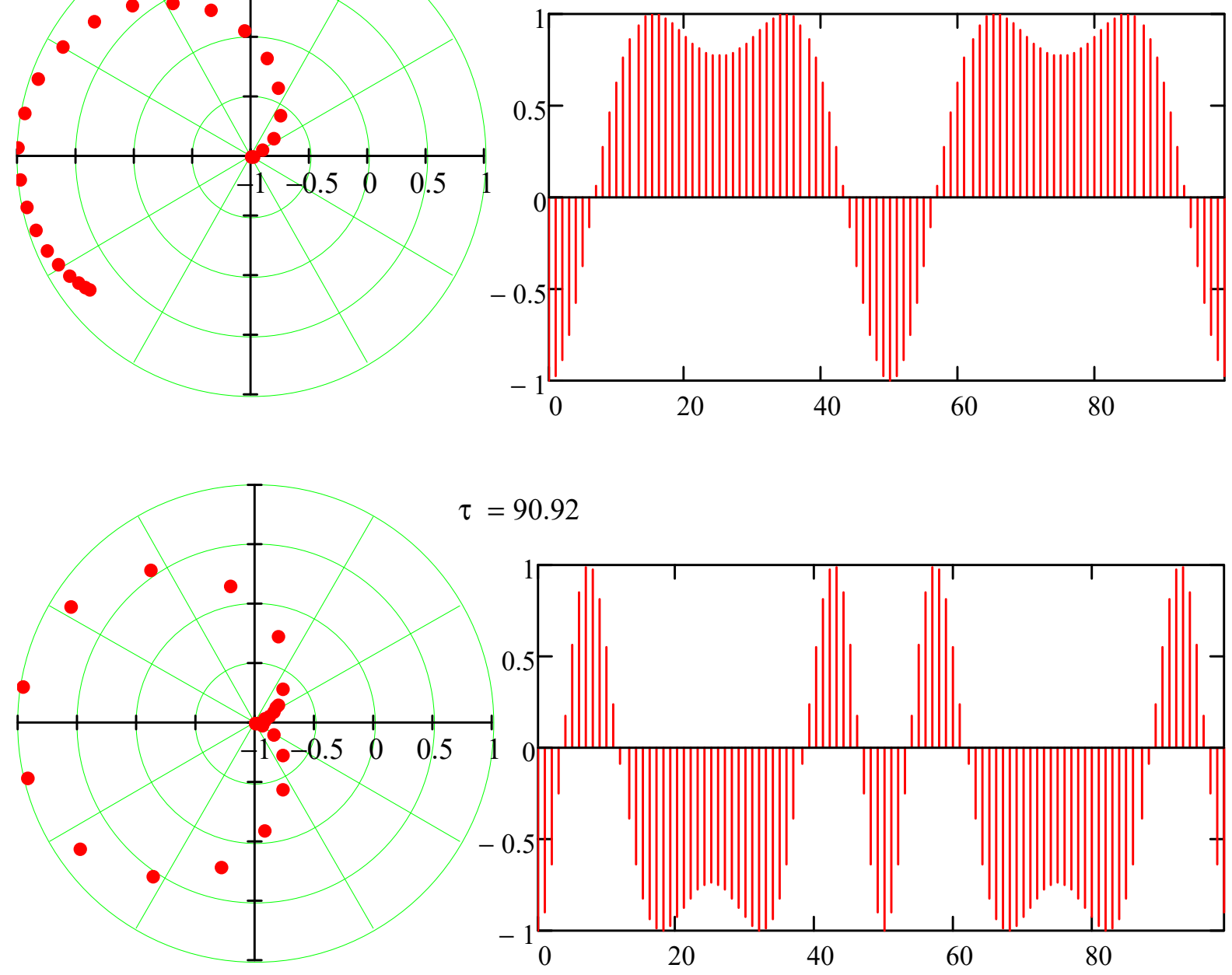

$\tau=90.92$

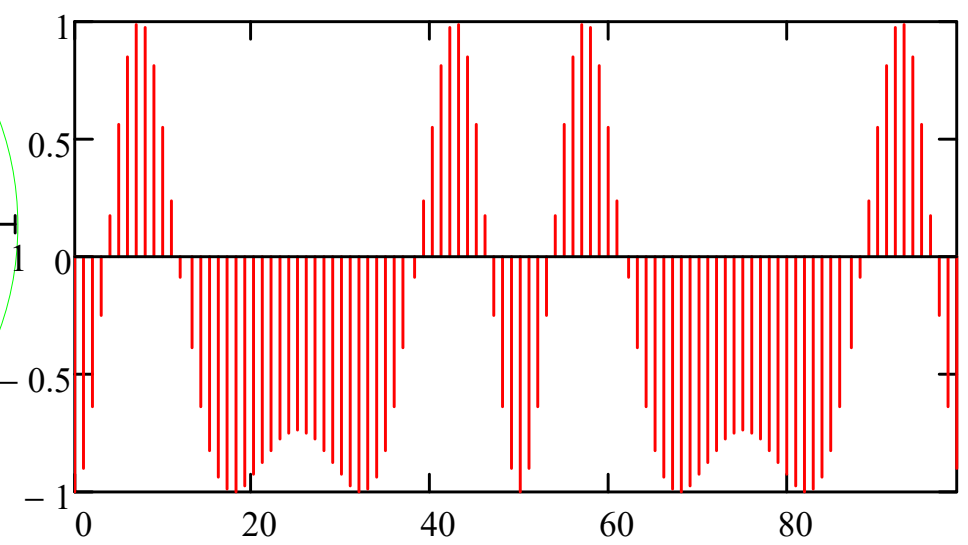

Fig. 2. The behavior of the real part of the population inversion $\operatorname{Re} M_{j}=\left|M_{j}\right| \cdot \operatorname{Cos} \Phi_{j}$ in each of the segments $0<j \leq S / 4$ in the phase space $\left(\operatorname{Cos} \Phi_{j} ; \Phi_{j}\right)$ (left), and in the diagrams for all segments $0<j \leq S=100$ (right) for points in time $\tau=45.47$

(above) and $\tau=90.92$ (below)

This type of attenuation is nonlinear attenuation and is characterized by a periodic energy exchange between the wave and the active medium, just as it happens in the case of Landau attenuation [11].

\section{Generation of a field in a waveguide filled with an excited active medium}

The description of this process is possible within the framework of the system of equations (12) and (13). We first consider the case of the absence of external losses in the waveguide ( $\delta_{1}=0$ ). The change in the relative number of quanta $N=N(\tau)$ in the system is shown in Fig.3.

It is not difficult to see that the periodic changes in the number of quanta in the nonlinear mode are attenuated due to the interference of the oscillations of population inversion in different segments. The behavior of the population inversion of individual segments at $\tau=72$ and $\tau=94$ is shown in detail in Fig.4. 


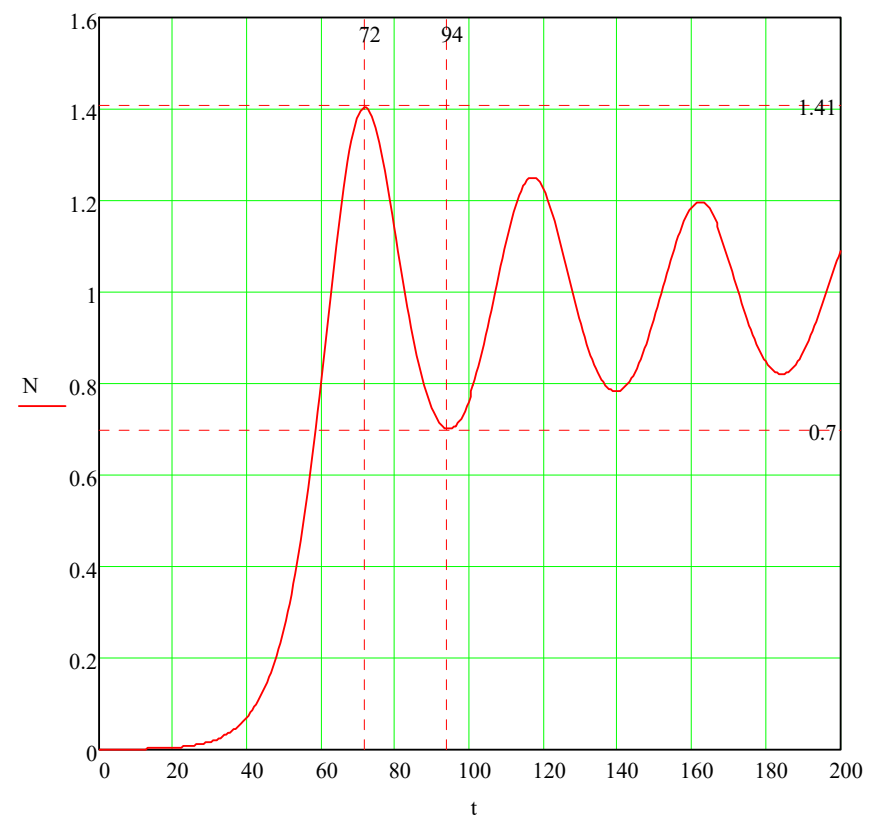

Fig. 3. The behavior of the relative number of quanta $N=N(\tau)$ in the system with time in the absence of loss $\left(\delta_{1}=0\right)$

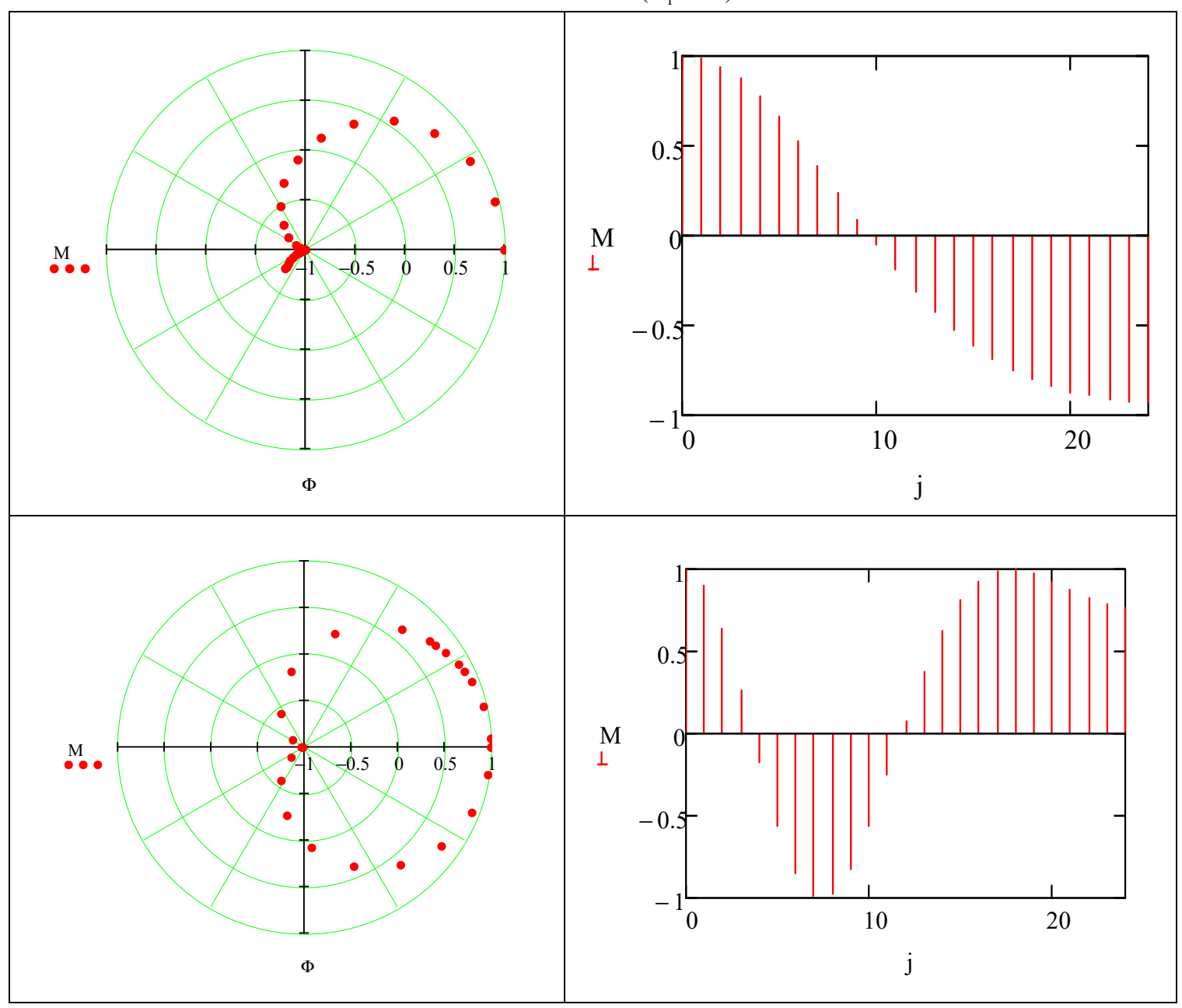

Fig.4. The behavior of the real part of the population inversion $\operatorname{Re} M_{j}=\left|M_{j}\right| \cdot \operatorname{Cos} \Phi_{j}$ in each of the segments $0<j \leq S / 4=25$ in the phase space $\left(\operatorname{Cos} \Phi_{j} ; \Phi_{j}\right)$ (left), and in the diagrams for all segments $0<j \leq S=100$ (right) for points at $\tau=72$ (above) and $\tau=94$ (below) 
Accounting for the absorption or removal of energy from the system corresponds to the case $\theta=\left(\delta / \Omega_{0}\right) / \gamma_{0}=\delta_{1} / \gamma_{0}>0$, where $\gamma_{0}=\gamma(\theta=0)=(d N / N d \tau)_{M A X}=0.138$ is the linear increment of instability development in the selected time scale at the linear stage of the process, obtained from the analysis of Fig. 5. It is easy to see that $\theta$ here the ratio of the field absorption decrement in the system in the absence of an active medium $\delta_{1}$ to the increment of the non-dissipative (or non-radiative) instability mode $\gamma_{0}=\gamma(\theta=0)$.

In the case of radiation from a waveguide, when $\delta \neq 0$, better to choose $N_{j}(\tau=0)=2 \frac{1}{S} \cdot N_{0} \cdot \operatorname{Sin}^{2}\left\{2 \pi \frac{j}{S}+\varphi\right\}$, where $\varphi$ is an constant phase associated with $\delta$ the following way. Generally speaking $\delta \approx \frac{c}{4 \pi}|E(x=0)|^{2} /\left(\frac{\left\langle\left. E\right|^{2}>\right.}{4 \pi} b\right)$, where $b$ is the waveguide length, where, by our assumption, a countable number of modes fit. It is easy to see that $|E(x=0)|^{2}=2<|E|^{2}>\operatorname{Sin}^{2} \varphi$ and $\delta \approx(2 c / b) \cdot \operatorname{Sin}^{2} \varphi$. It is important to note that if $b=m \lambda$, where $\lambda$ is the wavelength, then under conditions of a fixed attenuation value $\delta=\delta \approx(2 c \cdot m / b) \cdot \operatorname{Sin}^{2} \varphi$. The result of this does not change.

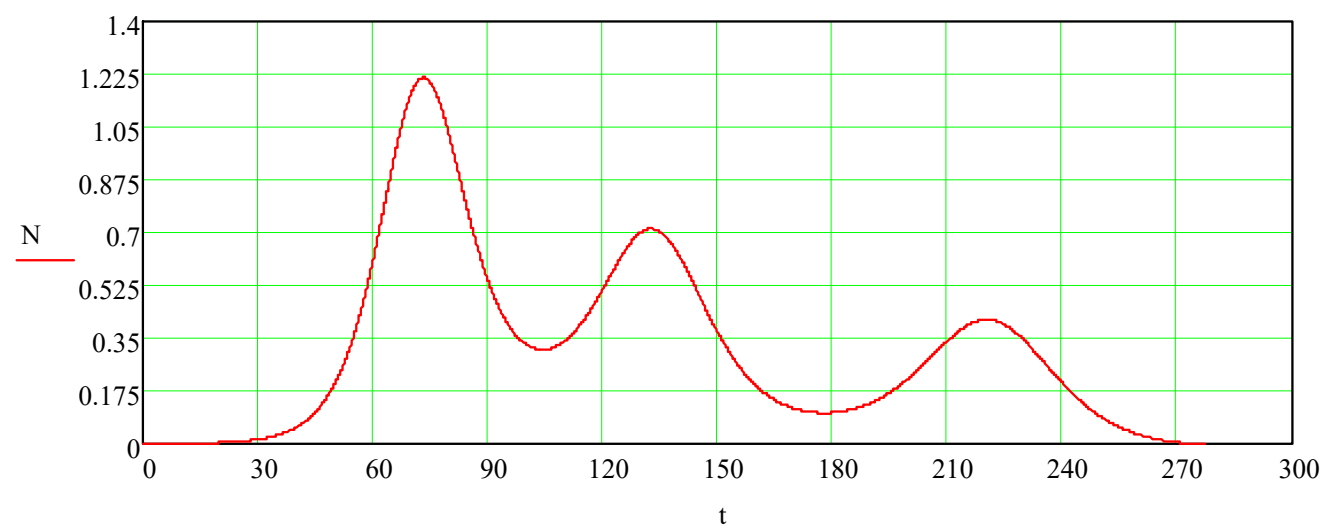

Fig. 5. The behavior of the relative number of quanta in a system with absorption (radiation) with time $\left(\delta_{1}=0.01\right.$, or $\left.\theta=0.073\right)$

In this case, the behavior of the number of quanta in the system acquires a damped oscillating character. It is useful to present the change in the linear increment of the process $d N / N d \tau$, the maximum attainable relative field intensity $N_{M A X}$, as well as the maximum energy flow from the system $(\theta \cdot N)_{M A X}$ as a function of $\theta$ (Fig. 6.).

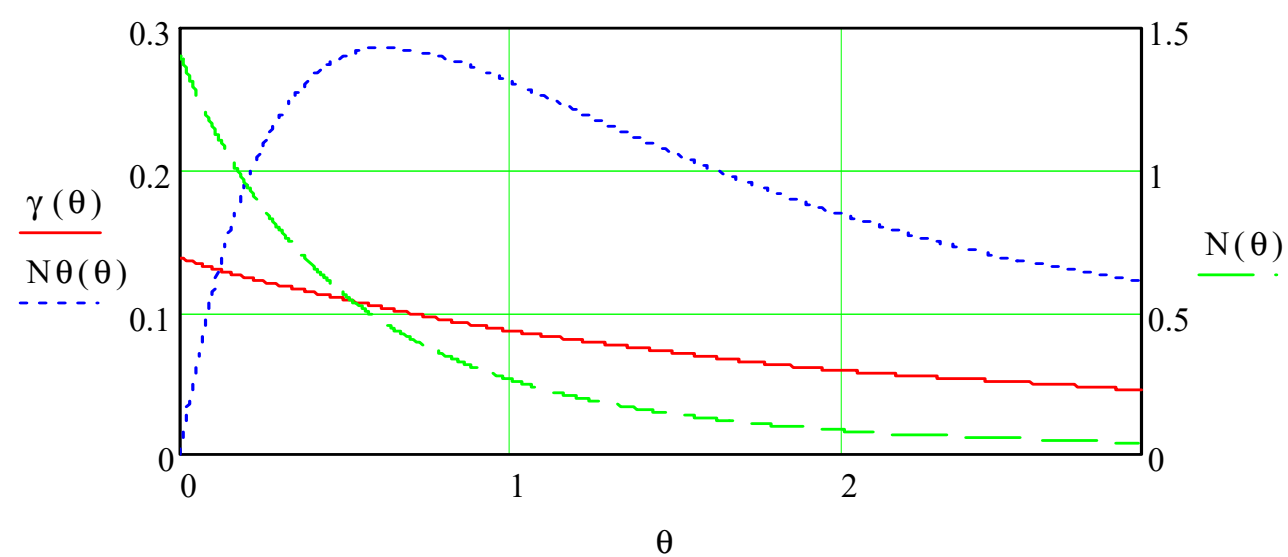

Fig. 6. The values of the linear increment of the process $d N / N d \tau$, the maximum attainable relative number of quanta $N_{M A X}$, as well as the maximum energy flux from the system $(\theta \cdot N)_{M A X}$ as a function of $\theta$

\section{CONCLUSION}

Above, we consider the energy exchange between the field, which is a standing wave in the waveguide and the active medium that fills its space. In each region of the waveguide space, the amplitude of the field of a standing wave formed due to partial or full reflection from the ends of the system is different and varies only with time. A quasiperiodic change in population inversion is determined by the Rabi frequency, which, is associated[1, 2], with the probability of induced radiation with a positive population inversion, or induced absorption with its negative value. An increase in population inversion leads to absorption of field quanta by the active medium, a decrease in population 
inversion, on the contrary, increases the number of quanta in the system. The total field is formed under the action of the interference of oscillations of population inversion of the local regions of the active medium in the entire volume of the waveguide.

The attenuation of a field of large amplitude to a waveguide filled with an unexcited active medium is nonlinear. In the developed mode, this process has the character of energy exchange between the field and the active medium. In this case, the wave attenuation is replaced by its growth, just as in the well-known case of Landau kinetic damping [11].

The nature of the excitation of a field by an inverted active medium in a waveguide is also discussed. Under the conditions of the final level of external losses, absorption or output of the radiation energy leads to a decrease in the field intensity in the active zone. The competition of the processes of radiation and absorption leads to the fact that the nature of oscillations (nutation) of population inversion at different points in the waveguide space is different. The interference of asynchronous spatially localized oscillations of population inversion in the waveguide volume leads to changes in the amplitude of the field. The change in the linear increment of the process $d N / N d \tau$, the maximum attainable relative field intensity $N_{M A X}$, and the maximum energy flow from the $\operatorname{system}(\theta \cdot N)_{M A X}$ as a function of $\theta$ which determine the level of wave energy absorption, are presented. Consideration of these problems is important for understanding the processes of generation of induced radiation, which, as noted by Towns Ch. [12], is to a large extent coherent radiation.

\section{ACKNOWLEDGEMENTS}

The authors are sincerely grateful to V. A. Buts and V. D. Khodusov for useful discussions and attention to the work.

\section{ORCID IDs}

Volodymyr Kuklin@http://orcid.org/0000-0002-0310-1582, Eugen Poklonskiy@https://orcid.org/0000-0001-5682-6694

\section{REFERENCES}

[1] A.S. Davydov, Quantum mechanics, (Fizmatgiz, Moscow, 1963), pp. 748. (in Russian)

[2] L. Allen and J. Eberly, Optical resonance and two-level atoms, (John Wiley and Sons, New York, London, Sydney, Toronto, 1975), pp. 222.

[3] S.G. Zeiger, Yu.L. Klimontovich, P.S. Landa, E.G. Lariontsev and E.E. Fradkin, Wave and fluctuation processes in lasers, (Nauka, Moscow, 1974), pp. 415. (in Russian)

[4] Landa P.S. Auto-oscillations in distributed systems, (Nauka, Moscow, 1983), pp. 320.

[5] G. Haken, Synergetics, (Mir, Moscow, 1980), pp. 403. (in Russian)

[6] V.V. Yanovskiy, Лекции о нелинейных явлениях. Том 1 [Lectures on nonlinear phenomena, Vol. 1], (Institute of Single Crystals, Kharkiv, 2006), pp. 456; V.V. Yanovskiy, Лекции о нелинейных явлениях. Том 2 [Lectures on nonlinear phenomena, Vol. 2], (Institute of Single Crystals, Kharkiv, 2007), pp. 448. (in Russian)

[7] V.A. Buts, Problems of Atomic Science and Technology, 5(6), 146-148 (2012).

[8] V.M. Vorobiev, V.M. Kuklin, Letters in ZhTF, 13(22), 1354-1360 (1987).

[9] E.V. Belkin, A.V. Kirichok and A.S. Petrenko, Problems of Atomic Science and Technology, 4, 299-301 (2010).

[10] V.M. Kuklin, Problems of atomic science and technology, Series "Plasma Electronics and New Methods of Acceleration", 4(122), 91-95 (2019).

[11] A.A. Andronov, Izvestiya Vuzov. Radiophysics, 4(5), 861-866 (1961). (in Russian)

[12] Ch. Towns, UFN, 88(3), 461-483 (1966). (in Russian)

\section{ОБ ОБМЕНЕ ЭНЕРГИЕЙ МЕЖДУ ПОЛЕМ И АКТИВНОЙ СРЕДОЙ ВОЛНОВОДА В.М. Куклин, Е.В. Поклонский \\ Харьковский национальный университет имени В. Н. Каразина, Харьков, Украина пл. Свободы 4, г. Харьков, Украина, 61022}

Работа на основе полуклассического описания представляет результаты изучения процессов поглощения и излучения поля в форме стоячей волны в волноводе, заполненном двухуровневой активной средой. В условиях пространственной неоднородности интенсивности поля возникает интерференция квазипериодических осцилляций инверсии населенностей в различных локальных областях волновода. Квазипериодическое изменение инверсии населенностей определяется частотой Раби, которая как известно, связана с вероятностью индуцированного излучения при положительной инверсии населенностей, или индуцированного поглощения при ее отрицательном значении.Так как изменение инверсии населенностей сопровождается поглощением или излучением квантов поля, это приводит к обмену энергией между полем и активной средой, размещенной в волноводе. Показано, что затухание поля большой амплитуды волноводе, заполненном невозбужденной активной средой, является нелинейным. В развитом режиме этот процесс носит характер обмена энергией между полем и активной средой. При этом затухание волны сменяется ее ростом, подобно тому, как это происходит в известном случае кинетического затухания Ландау. Конкуренция процессов излучения и поглощения приводит к тому, что характер осцилляций (нутации) инверсии населенностей в разных точках пространства волновода оказывается различным. И в этом случае именно интерференция несинхронных пространственно локализованных осцилляций инверсии населенностей в объеме волновода приводит к изменениям амплитуды поля. В работе обсуждается процесс возбуждения поля в волноводе предварительно инвертированной двухуровневой активной средой при учете внешних механизмов поглощения энергии колебаний. Рассмотрение этих проблем важно для понимания процессов генерации индуцированного излучения, которое как отметил Ч. Таундс в большой степени является излучением когерентным.

КЛЮЧЕВЫЕ СЛОВА: поглощения и излучения поля, двухуровневая активная среда, частота Раби, интерференция осцилляций инверсии населенностей. 


\section{ПРО ОБМІН ЕНЕРГІЕЮ МІЖ ПОЛЕМ ТА АКТИВНИМ СЕРЕДОВИЩЕМ ХВИЛЕВОДУ}

В.М. Куклін, Є.В. Поклонський

Харківський національний університет імені В.Н. Каразіна, Харків, Украӥна

м. Свободи 4, м. Харків, Україна, 61022

Робота на основі напівкласичного опису представляє результати вивчення процесів поглинання та генерації поля в формі стоячій хвилі в хвилеводі, що заповнений дворівневим активним середовищем. В умовах просторової неоднорідності інтенсивності поля виникає інтерференція осциляцій інверсії заселеності в різних локальних областях хвилеводу. Квазіперіодичні зміна інверсії заселеності визначається частотою Рабі, яка як відомо, пов'язана з ймовірністю індукованого випромінювання при позитивній інверсії заселеності, або індукованого поглинання при іiі негативному значенні. Так як зміна інверсії заселеності супроводжується поглинанням або випромінюванням квантів поля, це призводить до обміну енергією між полем та активним середовищем, що розміщено у хвилеводі. Показано, що затухання поля великої амплітуди в хвилеводі, що заповнений активним середовищем, $є$ нелінійним. У розвиненому режимі цей процес носить характер обміну енергією між полем і активним середовищем. При цьому загасання хвилі змінюється ії зростанням, подібно до того, як це відбувається у відомому випадку кінетичного загасання Ландау. Конкуренція процесів випромінювання $\mathrm{i}$ поглинання призводить до того, що характер осциляцій (нутацій) інверсії заселеності в різних точках простору хвилеводу виявляється різним. I в цьому випадку саме інтерференція несинхронних просторово локалізованих осциляцій інверсії заселеності в обсязі хвилеводу призводить до змін амплітуди поля. У роботі обговорюється також процес збудження поля в хвилеводі попередньо інвертованою дворівневим активним середовищем при обліку зовнішніх механізмів поглинання енергії коливань. Розгляд цих проблем важливий для розуміння процесів генерації індукованого випромінювання, яке як зазначив Ч. Таундс в великій мірі є випромінюванням когерентним.

КЛЮЧОВІ СЛОВА: поглинання і випромінювання поля, дворівневе активне середовище, частота Рабі, інтерференція осциляцій інверсії заселеності. 